\title{
Papers
}

\section{Angiotensin receptor blockers and risk of myocardial infarction: systematic review}

\author{
Michael A McDonald, Scot H Simpson, Justin A Ezekowitz, Gabor Gyenes, Ross T Tsuyuki
}

\begin{abstract}
Objective To evaluate the effect of angiotensin receptor blockers on the risk of myocardial infarction in patients at risk for cardiovascular events.

Design Systematic review of controlled trials of angiotensin receptor blockers.

Data sources Medline, Embase, Cochrane central register of controlled trials, hand search, and contact with investigators. Selection of studies Predefined criteria were used to select controlled clinical trials comparing use of angiotensin receptor blockers with angiotensin converting enzyme (ACE) inhibitors or placebo in patients at risk for cardiovascular events. Data were extracted for patients' characteristics, interventions, quality of trials, and rates of myocardial infarction.

Results 19 studies with 31569 patients were included in the analysis. Two studies investigated the use of angiotensin receptor blockers in hypertensive patients, four studies in patients with diabetes and nephropathy, 10 studies in patients with heart failure, and three in patients with recent myocardial infarction or ischaemic syndrome. 11 studies of 21062 patients allowed for comparison between angiotensin receptor blockers and placebo; nine studies of 10625 patients allowed for comparison between angiotensin receptor blockers and ACE inhibitors. Use of angiotensin receptor blockers was not associated with increased risk of myocardial infarction compared with placebo (odds ratio $0.94,95 \%$ confidence interval 0.75 to 1.16 ) nor with increased risk of myocardial infarction compared with ACE inhibitors (1.01, 0.87 to 1.16).

Conclusions Treatment with angiotensin receptor blockers was not associated with a significantly increased risk of myocardial infarction. The 95\% confidence intervals do, however, not exclude an increase of up to $16 \%$ in the risk of myocardial infarction or a reduction in risk of up to $25 \%$. Until further information specifically dealing with this issue is available from large prospective trials, our findings may alleviate recent concerns over the safety of this class of medications.
\end{abstract}

\section{Introduction}

Evidence is very strong for the use of angiotensin converting enzyme (ACE) inhibitors to reduce morbidity and mortality in patients with left ventricular dysfunction, in patients with recent myocardial infarction, and in patients who are otherwise at high risk for cardiovascular events. ${ }^{1-8}$ Angiotensin receptor blockers theoretically produce more complete inhibition of angiotensin II and are better tolerated than ACE inhibitors. ${ }^{9-11}$ Recent trials have, however, not shown their superiority and have been equivocal on their comparative effect. ${ }^{12-14}$ Verma and Strauss concluded that the use of angiotensin receptor blockers may even confer a risk of harm, specifically through their association with higher rates of myocardial infarction. ${ }^{15}$ This has caused much concern over using these agents, with many healthcare professionals and patients asking whether angiotensin receptor blockers should be avoided.

Recent, high profile withdrawals of commonly prescribed medications such as rofecoxib have heightened public awareness and concern over adverse drug reactions. In the case of angiotensin receptor blockers, we thought that it would be important to review systematically all available evidence before drawing conclusions on harm. We conducted a systematic review of all published controlled trials to determine the association of angiotensin receptor blockers and myocardial infarction.

\section{Methods}

We used standard systematic review techniques, as outlined by the Cochrane Collaboration. ${ }^{16}$ To evaluate the potential association between use of angiotensin receptor blockers and risk of myocardial infarction, we reviewed the medical literature to identify controlled trials comparing use of angiotensin receptor blockers with placebo therapy and with ACE inhibitors. We searched Medline, Embase, and the Cochrane central register of controlled trials, each from inception to December 2004. The search combined terms related to myocardial infarction ("myocardial infarction", "heart infarction", "death", "mortality") with terms related to angiotensin receptor blockers ("candesartan", "irbesartan", "losartan", "valsartan", "olmesartan", "telmisartan", "eprosartan"), using Boolean operators and database specific syntax. We also hand searched references from review articles and meta-analyses of angiotensin receptor blockers.

According to prespecified criteria, we included all original studies if they were controlled clinical trials, incorporated monotherapy with angiotensin receptor blockers in at least one of the treatment arms, reported myocardial infarction as either a prespecified outcome or as an adverse event, and were published in English. We excluded all secondary analyses if myocardial infarction events were provided in the parent study. Two reviewers (JAE, GG) independently screened abstracts for eligibility, rejecting those that were not controlled trials, and separate reviewers (MAM, SHS) independently assessed the full text of the remaining articles for final inclusion or exclusion. Disagreements were resolved by the vote of a third reviewer (JAE). We used standard criteria (allocation concealment, blinding, intention to treat analysis, loss to follow-up) to appraise study quality, in addition to quantitative quality assessment by using the scoring system developed by Jadad. ${ }^{17}$ 


\section{Data collection and outcome measures}

Two reviewers (MAM, SHS) used standardised data collection forms to extract data from studies for trial design, country of origin, patients' characteristics, interventions, and outcomes. We verified accuracy of data by comparing collection forms from each reviewer. We documented all reported myocardial infarctions, fatal or non-fatal, according to the definition used by the authors of individual studies and confirmed that cases represented actual numbers of patients with myocardial infarction rather than total numbers of myocardial events. Where data on myocardial infarction were included as a composite end point, we recorded the components of adverse cardiac outcomes that were provided and subsequently contacted study authors for rates of myocardial events. We also contacted authors for complete details on myocardial events for those studies in which only fatal or non-fatal myocardial infarctions were reported, and we ultimately used the best obtainable data in our analysis.

\section{Statistical analysis}

We entered data into $2 \times 2$ tables and used Cochrane Review Manager software (RevMan 4.2.7, Cochrane, Copenhagen, Denmark) to analyse our results. For studies that found no events in one of the treatment groups, the program uses a correction factor of 0.5 for all cells, to avoid division by 0 . For each study, we calculated odds ratios and combined them for the pooled odds ratio with 95\% confidence intervals. We used the standard DerSimonian and Laird random effects model for primary analysis $;{ }^{18}$ we chose this method a priori to account for potential variation between studies owing to differences in study populations. We also performed Mantel-Haenszel fixed effects analyses for estimating pooled odds ratios, to account best for the limited data available from some of the component studies. ${ }^{19}$ We used the $\mathrm{Q}$ statistic for all comparisons to evaluate heterogeneity of treatment effects between studies. We constructed standard funnel plots to investigate the potential for publication bias influencing the analysis. ${ }^{20}$

\section{Results}

Figure 1 summarises the process of identifying studies eligible for inclusion in our analysis. We reviewed the full text of 128 articles from 2742 studies identified from our initial literature search and hand search. A total of 24 studies met criteria for inclusion, and we could ascertain data on myocardial infarction for $19 .{ }^{13}{ }^{14}{ }^{21-37}$ We excluded four controlled studies identified in the literature search because the control arms were usual care, ${ }^{38}$ atenolol, ${ }^{39}$ amlodipine,$^{40}$ and hydrochlorothiazide. ${ }^{41}$ Agreement between two investigators for final study inclusion, measured by the $\kappa$ statistic, was 0.75 . All trials had a prospective, parallel design. Nine trials had the maximum Jadad score of 5 ; four trials scored 4, five scored 3, and one scored 2 (table 1). Allocation concealment was adequate in eight studies $(42 \%)$, inadequate in two studies (11\%), and unclear in the remaining nine studies $(47 \%)$. With the exception of the study by Di Pasquale et $\mathrm{al},{ }^{36}$ treatment was assigned in a randomised fashion. Participants were blinded in 19 studies (100\%), investigators in 17 studies $(89 \%)$, and outcome assessors in 18 (95\%). Finally, patients were analysed by the intention to treat principle in 15 of the studies (79\%).

In our data set, the study by Bakris et $\mathrm{al}^{22}$ compared losartan with both a placebo arm and an enalapril arm; we therefore included the study in both analyses. We did not use information from the amlodipine arm of the irbesartan diabetic nephropathy trial. ${ }^{25}$ Two studies investigated the use of angiotensin receptor blockers in hypertensive patients, ${ }^{21}{ }^{22}$ four studies in patients with

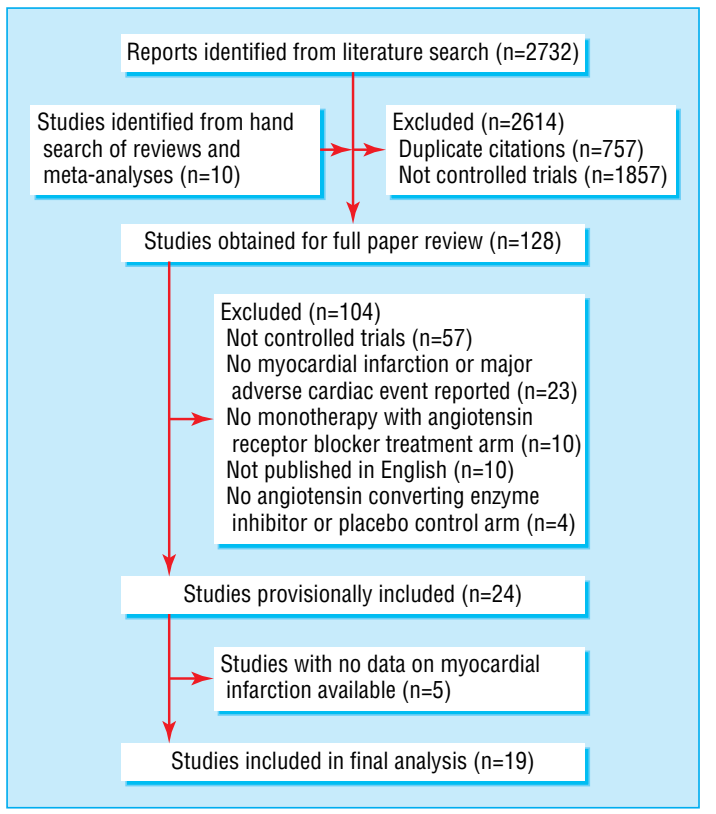

Fig 1 Flow diagram showing citations retrieved from literature searches and number of trials included in analysis

diabetes mellitus and nephropathy, ${ }^{23-26} 10$ studies in patients with heart failure,,$^{14-35}$ and three studies in patients with a recent myocardial infarction or ischaemic syndrome. ${ }^{13} 36{ }^{37}$ Myocardial infarction, major adverse cardiac events, or cardiac mortality was an adjudicated study end point in nine studies, $131421242528-3033$ whereas myocardial infarction was reported as an adverse event or was reported by the investigators in 10 studies that had primarily physiological or drug tolerability outcomes. $2232627313234-37$ Finally, nine studies allowed for comparison between angiotensin receptor blockers and ACE inhibitors, ${ }^{13} 14222633-37$ and 11 studies allowed for comparison between angiotensin receptor blockers and placebo. ${ }^{21-25}{ }^{27-32}$ Funnel plots for the angiotensin receptor blockers compared with placebo studies and angiotensin receptor blockers compared with ACE inhibitor studies are qualitatively symmetrical, indicating the absence of publication bias (fig 2). Other important study characteristics, including number of subjects, mean age, sex, and duration of follow-up, are summarised in the table.

\section{Effect of angiotensin receptor blockers compared with placebo on risk of myocardial infarction}

In this analysis we included two hypertension trials, three trials of patients with diabetes and nephropathy, and six heart failure trials, with a total of 10656 subjects allocated to treatment with angiotensin receptor blockers and 10406 subjects allocated to placebo. In the group that was treated with angiotensin receptor blockers, 436 myocardial infarctions occurred (4.09\%), compared with 450 myocardial infarctions in the placebo group (4.32\%). Overall, using angiotensin receptor blockers was not associated with a significant increase in the risk of myocardial infarction, with a pooled odds ratio of $0.94(95 \%$ confidence interval 0.75 to 1.16 ) from the random effects model (fig 3). Analysis using the fixed effects model similarly showed no significant association of using angiotensin receptor blockers with risk of myocardial infarction (pooled odds ratio $0.95,0.83$ to 1.09). 
Characteristics of controlled trials of angiotensin receptor blocker use that report myocardial infarction

\begin{tabular}{|c|c|c|c|c|c|c|c|}
\hline Study & Angiotensin receptor blocker & Control arm & No of subjects & $\begin{array}{l}\text { Mean age in } \\
\text { years }\end{array}$ & $\%$ women & $\begin{array}{l}\text { Follow-up in } \\
\text { years }\end{array}$ & Quality score $^{17}$ \\
\hline \multicolumn{8}{|l|}{ Subjects with hypertension } \\
\hline SCOPE $(2003)^{21}$ & Candesartan & Placebo & 4937 & 76.4 & 64.5 & 3.7 & 5 \\
\hline Bakris et al $(2002)^{22}$ & Losartan & Placebo and enalapril & 405 & 52.4 & 43.5 & 0.2 & 3 \\
\hline \multicolumn{8}{|c|}{ Subjects with type 2 diabetes and nephropathy } \\
\hline Haneda et al $(2004)^{23}$ & Candesartan & Placebo & 127 & 63.1 & 31.5 & 0.2 & 3 \\
\hline RENAAL $(2001)^{24}$ & Losartan & Placebo & 1513 & 60.0 & 36.8 & 3.4 & 5 \\
\hline IDNT $(2003)^{25}$ & Irbesartan & Placebo and amlodipine & 1715 & 58.9 & 33.8 & 2.6 & 5 \\
\hline DETAIL $(2004)^{26}$ & Telmisartan & Enalapril & 250 & 60.6 & 27.2 & 5.0 & 5 \\
\hline \multicolumn{8}{|l|}{ Subjects with heart failure } \\
\hline ARCH-J $(2003)^{27}$ & Candesartan & Placebo & 292 & 63.7 & 15.4 & 0.4 & 3 \\
\hline CHARM-Added (2003) ${ }^{28}$ & Candesartan & Placebo & 2548 & 64.0 & 21.3 & 3.4 & 5 \\
\hline CHARM-Alternative $(2003)^{29}$ & Candesartan & Placebo & 2028 & 66.6 & 31.9 & 2.8 & 5 \\
\hline CHARM-Preserved $(2003)^{30}$ & Candesartan & Placebo & 3023 & 67.2 & 40.1 & 3.1 & 5 \\
\hline SPICE $(2000)^{31}$ & Candesartan & Placebo & 270 & 65.0 & 31.1 & 0.2 & 4 \\
\hline Val-HeFT $(2001)^{32}$ & Valsartan & Placebo & 5010 & 62.7 & 20.0 & 1.9 & 5 \\
\hline ELITE $(1997)^{33}$ & Losartan & Captopril & 722 & 73.5 & 30.6 & 0.9 & 4 \\
\hline ELITE II $(2000)^{14}$ & Losartan & Captopril & 3152 & 71.5 & 30.6 & 1.5 & 4 \\
\hline HEAVEN $(2002)^{34}$ & Valsartan & Enalapril & 141 & 67.5 & 26.2 & 0.2 & 4 \\
\hline REPLACE $(2001)^{35}$ & Telmisartan & Enalapril & 378 & 64.0 & 11.0 & 0.2 & 3 \\
\hline \multicolumn{8}{|c|}{ Subjects with recent myocardial infarction or ischaemic syndrome } \\
\hline Di Pasquale et al (1999) ${ }^{36}$ & Losartan & Captopril & 73 & 63.5 & 27.4 & 0.2 & 3 \\
\hline OPTIMAAL $(2002)^{13}$ & Losartan & Captopril & 5477 & 67.4 & 28.8 & 2.7 & 5 \\
\hline Spinar et al $(2000)^{37}$ & Losartan & Captopril & 201 & 65.9 & 29.9 & 0.1 & 2 \\
\hline
\end{tabular}

SCOPE=study on cognition and prognosis in the elderly; RENAAL=reduction of end points in NIDDM with the angiotensin II antagonist losartan; IDNT=irbesartan diabetic nephropathy trial; DETAIL=diabetics exposed to telmisartan and enalapril; ARCH-J=assessment of response to candesartan in heart failure in Japan; CHARM=candesartan in heart failure: assessment of reduction in mortality and morbidity; SPICE=study of patients intolerant of converting enzyme inhibitors; Val-HeFT=valsartan in heart failure trial; ELITE=evaluation of losartan in the elderly; HEAVEN=heart failure valsartan exercise capacity evaluation; REPLACE=replacement of angiotensin converting enzyme inhibition; OPTIMAAL=optimal trial in myocardial infarction with the angiotensin II antagonist losartan.

Effect of angiotensin receptor blockers compared with angiotensin converting enzyme inhibitors on risk of myocardial infarction

Figure 4 shows the results of the comparison of treatment with angiotensin receptor blockers and ACE inhibitors with respect to risk of myocardial infarction in one hypertension study, one diabetes and nephropathy study, four heart failure studies, and three recent studies of myocardial infarction or ischaemic

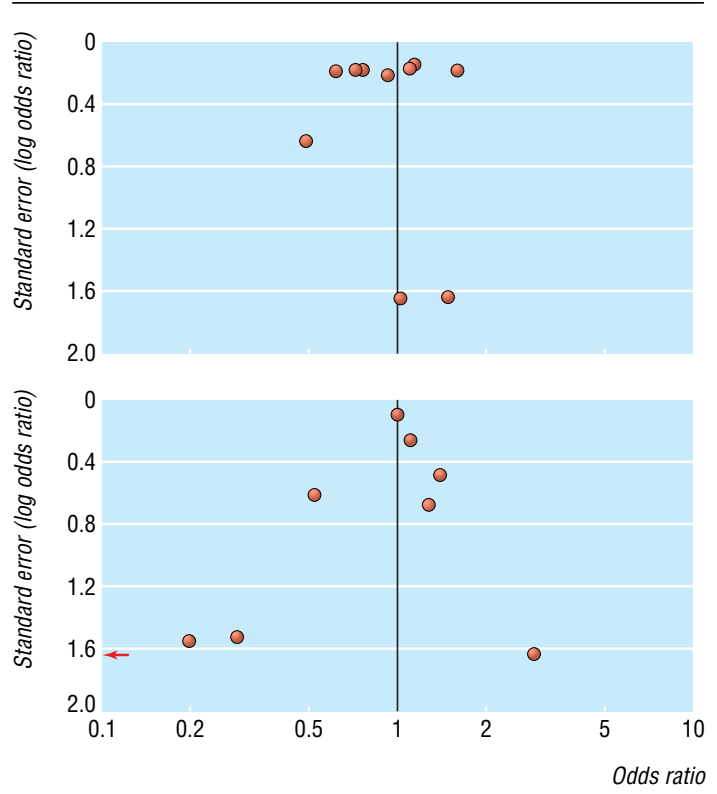

Fig 2 Top: Funnel plot of studies comparing angiotensin receptor blockers and placebo. Bottom: Funnel plot of studies comparing angiotensin receptor blockers and angiotensin converting enzyme (ACE) inhibitors syndrome. Among 5406 patients receiving angiotensin receptor blockers, 435 myocardial events occurred $(8.05 \%)$, compared with 433 events $(8.30 \%)$ in 5219 patients receiving ACE inhibitors, resulting in a pooled odds ratio close to unity (1.01, 0.87 to 1.16 by random effects analysis; $1.00,0.87$ to 1.16 by fixed effects analysis). This summary effect size was driven mainly by the OPTIMAAL study, ${ }^{13}$ which accounted for $86.8 \%$ of the weighted odds ratio in the random effects model, with an individual study odds ratio of 1.01 (0.87 to 1.16$)$.

\section{Discussion}

Treatment with angiotensin receptor blockers was not associated with an increased risk of myocardial infarction, according to our systematic review of 19 trials with 31569 subjects. With a pooled odds ratio very close to unity in our analyses for angiotensin receptor blockers compared with placebo and compared with ACE inhibitor, our results indicate that an aggregate of patients with hypertension, diabetes and nephropathy, heart failure and left ventricular dysfunction, and patients with recent myocardial infarction or ischaemic syndrome were not at greater risk of myocardial infarction when treated with different angiotensin receptor blockers.

\section{Angiotensin receptor blockers versus placebo}

In our analysis of treatment with angiotensin receptor blockers compared with placebo including 21062 patients, we found no significant difference between groups in the incidence of myocardial infarction, although the $95 \%$ confidence intervals cannot rule out an increased risk of myocardial infarction of up to $16 \%$ or a reduced risk of up to $25 \%$. Our evaluation of angiotensin receptor blockers compared with placebo included the CHARM-alternative trial, ${ }^{29}$ which contributed more than $13 \%$ to the weighted pooled odds ratio and was the only study to 
show an increase in myocardial infarction rates with use of angiotensin receptor blockers that reached significance. In this study, patients with left ventricular dysfunction and heart failure who were intolerant to ACE inhibitors were randomised to the angiotensin receptor blocker candesartan or placebo. Despite the observed increased incidence of myocardial infarction in the candesartan group, cardiovascular mortality fell overall with treatment with angiotensin receptor blockers. In contrast, among other patients with heart failure and similar background cardiovascular risk, including patients being treated with concomitant ACE inhibitors in the CHARM-added ${ }^{28}$ and ValHeFT ${ }^{32}$ trials, the point estimates were distributed across the 1.0 odds ratio, imply- ing that using angiotensin receptor blockers is itself not significantly associated with risk of myocardial infarction. Although we have not shown a clear relative benefit on myocardial infarction of treatment with angiotensin receptor blockers compared with placebo, our results indicate that this class of medications is unlikely to be harmful.

\section{Angiotensin receptor blockers versus ACE inhibitors}

As ACE inhibitors have been shown unequivocally to reduce cardiac morbidity and mortality among patients at risk for cardiovascular events, a prespecified comparative analysis with ACE inhibitors was necessary to assess better the safety and rela-

\begin{tabular}{|c|c|c|c|c|c|c|c|}
\hline Study & $\begin{array}{l}\text { ARB group } \\
(\mathrm{n} / \mathrm{N})\end{array}$ & $\begin{array}{l}\text { Placebo group } \\
(\mathrm{n} / \mathrm{N})\end{array}$ & & $\begin{array}{l}\text { Odds ratio (random) } \\
\quad(95 \% \mathrm{Cl})\end{array}$ & & $\begin{array}{l}\text { Weight } \\
(\%)\end{array}$ & $\begin{array}{l}\text { Odds ratio (random) } \\
(95 \% \mathrm{Cl})\end{array}$ \\
\hline SCOPE $2003^{21}$ & $70 / 2477$ & $63 / 2460$ & & & & 14.45 & $1.11(0.78$ to 1.56$)$ \\
\hline Bakris et al $2002^{22}$ & $1 / 118$ & $0 / 58$ & & & & 0.45 & 1.49 (0.06 to 37.23$)$ \\
\hline \multicolumn{8}{|c|}{ Type 2 diabetes and nephropathy } \\
\hline Haneda et al $2004^{23}$ & $1 / 95$ & 0/32 & 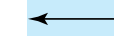 & & $\rightarrow$ & 0.45 & 1.03 (0.04 to 25.96$)$ \\
\hline RENAAL $2001^{24}$ & $50 / 751$ & $68 / 762$ & & $\rightarrow$ & & 13.42 & $0.73(0.50$ to 1.06$)$ \\
\hline IDNT $2003^{25}$ & $44 / 579$ & $46 / 569$ & & & & 12.03 & $0.94(0.61$ to 1.44$)$ \\
\hline \multicolumn{8}{|l|}{ Heart failure } \\
\hline ARCH-J $2003^{27}$ & 0/148 & $0 / 144$ & & & & & Not estimable \\
\hline CHARM-added $2003^{28}$ & $44 / 1276$ & 69/1272 & & ․ & & 13.23 & 0.62 (0.42 to 0.92$)$ \\
\hline CHARM-alternative $2003^{29}$ & 75/1013 & $48 / 1015$ & & $\because-$ & & 13.61 & 1.61 (1.11 to 2.34$)$ \\
\hline CHARM-preserved $2003^{30}$ & $57 / 1514$ & $73 / 1509$ & & & & 14.18 & $0.77(0.54$ to 1.10$)$ \\
\hline SPICE $2000^{31}$ & $5 / 179$ & $5 / 91$ & & & & 2.63 & $0.49(0.14$ to 1.75$)$ \\
\hline Val-HeFT $2001^{32,42}$ & $89 / 2506$ & $78 / 2494$ & & - & & 15.55 & $1.14(0.84$ to 1.55$)$ \\
\hline Total $(95 \% \mathrm{Cl})$ & 10656 & 10406 & & 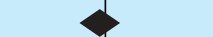 & & 100.00 & $0.94(0.75$ to 1.16$)$ \\
\hline \multicolumn{8}{|c|}{ Total events: 436 (ARB group), 450 (placebo group) } \\
\hline \multicolumn{3}{|c|}{ Test for heterogeneity: $\chi^{2}=18.72, d f=9, P=0.03, I^{2}=51.9 \%$} & $0.1 \quad 0.2$ & $0.5 \quad 1$ & 10 & & \\
\hline \multicolumn{3}{|c|}{ Test for overall effect: $z=0.60, P=0.55$} & \multicolumn{2}{|c|}{$\begin{array}{l}\text { Favours angiotensin } \\
\text { receptor blockers }\end{array}$} & $\begin{array}{l}\text { Favours } \\
\text { placebo }\end{array}$ & & \\
\hline
\end{tabular}

Fig 3 Effect of angiotensin receptor blockers compared with placebo on risk of myocardial infarction

$\begin{aligned} & \text { Study } \\ & \text { Hypertension }\end{aligned}$
$\begin{aligned} & \text { Bakris et al 2002 } 22 \\ & \text { (n/N) }\end{aligned}$

Fig 4 Effect of angiotensin receptor blockers compared with angiotensin converting enzyme inhibitors on risk of myocardial infarction 
tive effect of angiotensin receptor blockers on the risk of myocardial infarction. In this analysis, we found no difference in this risk between the arms receiving angiotensin receptor blockers and ACE inhibitors. Similar to our analysis comparing angiotensin receptor blockers with placebo, the 95\% confidence interval included an up to $16 \%$ increased risk of myocardial infarction down to a 13\% reduction with angiotensin receptor blockers. Although our evaluation included nine component studies, all of which had 95\% confidence intervals crossing 1.0 , the overall effect was most heavily influenced by the OPTIMAAL study. ${ }^{13}$ In this trial, the angiotensin receptor blocker losartan was not found to be superior or non-inferior to the ACE inhibitor captopril with respect to overall mortality in very high risk patients after myocardial infarction, and the rate of reinfarction was virtually identical between groups. Although angiotensin receptor blockers were found to be non-superior in large randomised controlled trials, ${ }^{12-14} 43$ our finding supports the notion that they may be a safe and effective alternative for a select group of heart failure patients not taking ACE inhibitors, as shown by a recent meta-analysis. ${ }^{44}$

\section{Angiotension receptor blockers do not increase risk of myocardial infarction}

Our finding that angiotensin receptor blockers are not associated with an increased risk of myocardial infarction stands in contrast to the editorial by Verma and Strauss, ${ }^{15}$ which drew attention to results from several recent studies, including the VALUE trial $^{40}$ the CHARM-alternative ${ }^{29}$ and CHARMpreserved $^{30}$ trials, and the SCOPE, ${ }^{21}$ LIFE, ${ }^{39}$ and RENAAL ${ }^{24}$ trials. Our analysis, which included all but the $\mathrm{LIFE}^{39}$ and VALUE ${ }^{40}$ trials (excluded from our analysis because they did not have placebo or ACE inhibitor control groups), highlights the importance of assessing all available evidence by using systematic methods, before drawing conclusions.

\section{Limitations}

Although we tried to conduct a thorough review of the existing literature, our study has limitations inherent to any systematic review. Firstly, we were unable to obtain data on myocardial infarction events from all studies identified in our literature search. Perhaps most notably, data on myocardial infarction from the valsartan in acute myocardial infarction trial (VALIANT), ${ }^{12}$ which included 14703 patients, were not available for our analysis. We informally tested the potential impact of the unavailable data from this trial by assuming a "worst case scenario" in which all 919 patients admitted to hospital for myocardial infarction or heart failure, or both, in the valsartan arm of VALIANT had a myocardial infarction, and 0 patients in the captopril arm were admitted to hospital for myocardial infarction. In this scenario, the pooled odds ratio in our ACE-inhibitor controlled analysis changed from 1.01 (0.87 to 1.16$)$ to 1.40 (0.25 to 7.80). Despite the addition of almost 10000 patients to our study total, we would still observe no significant association between use of angiotensin receptor blockers and myocardial infarction risk compared with ACE inhibitors. We would further speculate that data from other potential sources not included in our study (from smaller trials, unpublished reports) would not significantly influence our results. Similarly, excluding the non-randomised trial ${ }^{36}$ would have little impact on our findings. Other limitations of our study include potential variation in the definition of myocardial infarction between studies, the possibility of effects that are specific to angiotensin receptor blockers and dose dependent, and the potential confounding influence of other treatments.

\section{What is already known on this topic}

Evidence from randomised controlled trials of angiotensin receptor blockers have shown variable effects on cardiovascular events

A recent editorial by Verma and Strauss implied that angiotensin receptor blockers increase the risk of myocardial infarction

\section{What this study adds}

Our systematic review of all available data on angiotensin receptor blockers shows a neutral (not increased) impact of these agents on myocardial infarction

Although ACE inhibitors remain the agents of choice to reduce myocardial infarction, patients and healthcare providers need not worry about angiotensin receptor blockers increasing patients' risk for myocardial infarction

\section{Conclusions}

We conducted a systematic quantitative review of angiotensin receptor blockers and the risk of myocardial infarction. Until information specifically dealing with this issue is available from large, prospectively designed trials, such as the ONTARGET/ TRANSCEND trials, ${ }^{45}$ we must rely on the weight of available evidence to guide decisions on the management of individual patients' decisions. Our results show that treatment with angiotensin receptor blockers is not associated with increased incidence of myocardial infarction.

The authors thank Janice Varney, MLIS, for her help in conducting the literature search. The authors also thank the individual trialists for sharing data from their original studies.

Contributors: All authors took part in the planning and design of the study. MAM, SHS, JAE, and GG did the data collection. SHS did the statistical analyses. All participated in the interpretation of the data. MAM and SHS wrote the first draft of the paper. All authors reviewed and revised the paper for important intellectual content. RTT provided leadership for the study, is the senior and corresponding author, and takes responsibility for the content.

\section{Funding: None.}

Competing interests: SHS has received honorariums from Merck Frosst and Sanofi-Aventis. GG has received travel grants and honorariums from Aventis, Pfizer, Servier, Novartis, Biovail, AstraZeneca, Merck-Schering, Merck Frosst, and Procter and Gamble. RTT is supported by the Merck Frosst Chair in Patient Health Management from the University of Alberta. $\mathrm{He}$ is a member of the Cardiovascular Advisory Board of Merck Frosst and has received honorariums and research grants from Merck Frosst, Merck-Schering, Pfizer, Sanofi-Aventis, and Novartis.

Ethical approval: Not required.

1 The SOLVD Investigators. Effect of enalapril on survival in patients with reduced left ventricular ejection fractions and congestive heart failure. N Engl J Med 1991;325:293302.

2 The CONSENSUS Trial Study Group. Effects of enalapril on mortality in severe congestive heart failure. Results of the cooperative north Scandanavian enalapril survival study (CONSENSUS). N Engl J Med 1987;316:1429-35.

3 The SOLVD Investigators. Effect of enalapril on mortality and the development of heart failure in asymptomatic patients with reduced left ventricular ejection fractions. NEngl J Med 1992;327:685-91.

4 Pfeffer MA, Braunwald E, Moye LA, Basta L, Brown EJ, Cuddy TE, et al. Effect of captopril on mortality and morbidity in patients with left ventricular dysfunction after myocardial infarction: results of the Survival and Ventricular Enlargement trial. $N$ Engl J Med 1992;327:669-77.

5 The Acute Infarction Ramipril Efficacy (AIRE) Study Investigators. Effect of ramipril on mortality and morbidity of survivors of acute myocardial infarction with clinical evion mortality and morbidity of survivors of acu,

6 Swedberg K, Held P, Kjekshus J, Rasmussen K, Ryden L, Wedel H. Effects of the early administration of enalapril on mortality in patients with acute myocardial infarction. Results of the cooperative new Scandinavian enalapril survival study II (CONSENSUS II). N Engl J Med 1992;327:678-84 
7 Ambrosioni E, Borghi C, Magnani G. The effect of the angiotensin-converting-enzyme nhibitor zofenopril on mortality and morbidity after anterior myocardial infarction. $N$ Engl J Med 1995;332:80-5

8 The Heart Outcomes Prevention Evaluation Study Investigators. Effects of an angiotensin-converting-enzyme inhibitor, ramipril, on cardiovascular events in high-risk patients. N Engl J Med 2000;342:145-53.

9 Levy BI. Can angiotensin II type II receptors have deleterious effects in cardiovascular disease? Implications for therapeutic blockade of the renin-angiotensin system. Circulation 2004;109:8-13.

10 Swedberg K, McMurray JJV. Angiotensin receptor blockers and heart failure: still CHARMing after VALIANT? Eur Heart J 2004;25:357-8

11 McMurray JJV. Angiotensin receptor blockers for chronic heart failure and acute myocardial infarction. Heart 2001;86:97-103.

12 Pfeffer MA, McMurray JJV, Velazquez EJ, Rouleau JL, Kober L, Maggioni AP, et al. Valsartan, captopril, or both in myocardial infarction complicated by heart failure, left ventricular dysfunction, or both. N Engl J Med 2003;349:1893-906.

13 Dickstein K, Kjekshus J, the OPTIMAAL Steering Committee, for the OPTIMAAL Study Group. Effects of losartan and captopril on mortality and morbidity in high-risk patients after acute myocardial infarction: the OPTIMAAL randomised trial. Lance 2002:360:752-60.

14 Pitt B, Poole-Wilson PA, Segal R, Martinez FA, Dickstein K, Camm AJ, et al. Effect of losartan compared with captopril on mortality in patients with symptomatic heart failure: randomised trial-the losartan heart failure survival study ELITE II. Lance 2000;355:1582-7.

15 Verma S, Strauss M. Angiotensin receptor blockers and myocardial infarction. BMJ 2004;329:1248-9.

16 Alderson P, Green S, Higgins JPT, eds. Cochrane reviewers' handbook 4.2.2 [updated December 2003]. www.cochrane.org/resources/handbook/hbook.htm (accessed 23 Aug 2005)

17 Jadad AR, Moore RA, Carroll D, Jenkinson C, Reynolds DJ, Gavaghan DJ, et al. Assessing the quality of reports of randomized clinical trials: is blinding necessary? Control Clin Trials 1996;17:1-12.

18 DerSimonian R, Laird N. Meta-analysis in clinical trials. Control Clin Trials 1986;7:17788 .

19 Mantel N, Haenszel W. Statistical aspects of the analysis of data from retrospective studies of disease. J Natl Cancer Inst 1959;22:719-48.

20 Light RJ, Pillemer DB. Summing up. The science of reviewing research. Cambridge, Mass: Harvard University Press, 1984

21 Lithell H, Hansson L, Skoog I, Elmfeldt D, Hofman A, Olofsson B, et al. The study on cognition and prognosis in the elderly (SCOPE): principal results of a randomized double- blind intervention trial.J Hypertens 2003;21:875-86.

22 Bakris G, Sica D, Ram V, Fagan T, Vaitkus PT, Anders RJ. A comparative trial of controlled-onset, extended-release verapamil, enalapril, and losartan on blood pressure and heart rate changes. Am J Hypertens 2002;15:53-7.

23 Haneda M, Kikkawa R, Sakai H, Kawamori. Antiproteinuric effect of candesartan cilexetil in Japanese subjects with type 2 diabetes and nephropathy. Diabetes Res Clin Pract 2004:66:87-95.

24 Brenner BM, Cooper ME, de Zeeuw D, Keane WF, Mitch WE, Parving HH, et al. Effects of losartan on renal and cardiovascular outcomes in patients with type 2 diabetes and nephropathy. N Eng J Med 2001;345:961-9.

25 Berl T, Hunsicker LG, Lewis JB, Pfeffer MA, Porush JG, Rouleau JL, et al. Cardiovascular outcomes in the irbesartan diabetic nephropathy trial of patients with type 2 diabetes and overt nephropathy. Ann Intern Med 2003;138:542-9

26 Barnett AH, Bain SC, Bouter P, Karlberg B, Madsbad S, Jervell J, et al Angiotensin-receptor blockade versus converting-enzyme inhibition in type 2 diabetes angiotensin-receptor blockade versus converting-e

27 Matsumori A, on behalf of the assessment of response to candesartan in heart failure in Japan (ARCH-J) study investigators. Efficacy and safety of oral candesartan cilexetil in patients with congestive heart failure. Eur J Heart Fail 2003;5:669-77.

28 McMurray JJV, Ostergren J, Swedberg K, Granger CB, Held P, Michelson EL, et al. Effects of candesartan in patients with chronic heart failure and reduced left-ventricular systolic function taking angiotensin-converting-enzyme inhibitors: the CHARM-Added trial. Lancet 2003;362:767-71.

29 Granger CB, McMurray IJV, Yusuf S, Held P, Michelson EL, Olofsson B, et al. Effects of candesartan in patients with chronic heart failure and reduced left-ventricular systolic function intolerant to angiotensin-converting-enzyme inhibitors: the CHARMalternative trial. Lancet 2003;362:772-6.

30 Yusuf S, Pfeffer MA, Swedberg K, Granger CB, Held P, McMurray JJV, et al. Effects of candesartan in patients with chronic heart failure and preserved left-ventricular ejection fraction: the CHARM-preserved Trial. Lancet 2003;362:777-81.
31 Granger CB, Ertl G, Kuch J, Maggioni AP, McMurray J, Rouleau JL, et al. Randomized trial of candesartan cilexetil in the treatment of patients with congestive heart failure and a history of intolerance to angiotensin-converting enzyme inhibitors. Am Heart J 2000;139:609-17.

32 Cohn JN, Tognoni G, for the Valsartan Heart Failure Trial Investigators. A randomized trial of the angiotensin-receptor blocker valsartan in chronic heart failure. N EnglJ Med 2001;345:1667-75.

33 Pitt B, Segal R, Martinez FA, Meurers G, Cowley AJ, Thomas I, et al. Randomised trial of losartan versus captopril in patients over 65 with heart failure (evaluation of losartan in the elderly study, ELITE). Lancet 1997;349:747-52

34 Willenheimer R, Helmers C, Pantev E, Rydberg E, Lofdahl P, Gordon A, for the Heart Failure Valsartan Exercise Capacity Evaluation (HEAVEN) Study Group. Safety and efficacy of valsartan versus enalapril in heart failure patients. Int J Cardiol 2002;85:26170 .

35 Dunselman PHJM. Effects of the replacement of the angiotensin converting enzyme inhibitor enalapril by the angiotensin II receptor blocker telmisartan in patients with congestive heart failure. The replacement of angiotensin converting enzyme inhibition (REPLACE) investigators. Int J Cardiol 2001;77:131-8.

36 Di Pasquale P, Bucca V, Scalzo S, Cannizzaro S, Giubilato A, Paterna S. Does the addition of losartan improve the beneficial effects of ACE inhibitors in patients with anterior myocardial infarction? A pilot study. Heart 1999;81:606-11.

37 Spinar J, Vitovec J, Spinarova L, Pluhacek L, Fischerova B, Toman J. A comparison of intervention with losartan or captopril in acute myocardial infarction. Eur J Heart Fail 2000:2:91-100.

38 Kondo J, Sone T, Tsuboi H, Mukawa H, Morishima I, Uesugi M, et al. Effects of low-dose angiotensin II receptor blocker candesartan on cardiovascular events in patients with coronary artery disease. Am Heart J 2003;146:e20.

39 Dahlof B, Devereux RB, Kjeldsen SE, Julius S, Beevers G, de Faire U, et al. Cardiovascular morbidity and mortality in the Losartan Intervention For Endpoint reduction in hypertension study (LIFE): a randomised trial against atenolol. Lancet 2002;359:9951003.

40 Julius S, Kjeldsen SE, Weber M, Brunner HR, Ekman S, Hansson L, et al. Outcomes in hypertensive patients at high cardiovascular risk treated with regimens based on valsartan or amlodipine: the VALUE randomised trial. Lancet 2004;363:2022-31.

41 Lindholm LH, Persson M, Alaupovic P, Carlberg B, Svensson A, Samuelsson O. Metabolic outcomes during 1 year in newly detected hypertensives: results of the antihypertensive treatment and lipid profile in a north of Sweden efficacy evaluation (ALPINE tensive treatment and lipid profile in a
study). J Hypertens 2003:21:1563-74.

42 Targum SL, Hung HMJ. Medical-statistical review: NDA 20-665/SE1-016 and 21-283/ SE-001 Diovan (valsartan) capsules and tablets. 2001. www.fda.gov/cder/foi/nda/ 2002/21-283S001_Diovan_medr_P3.pdf (accessed 2 Apr 2005)

43 McKelvie RS, Yusuf S, Pericak D, Avezum A, Burns RJ, Probstfield J, et al. Comparison of candesartan, enalapril, and their combination in congestive heart failure. The randomized evaluation of strategies for left ventricular dysfunction (RESOLVD) pilot study. Circulation 1999;100:1056-64.

44 Lee VC, Rhew DC, Dylan M, Badamgarav E, Braunstein GD, Weingarten SR Meta-analysis: angiotensin-receptor blockers in chronic heart failure and high-risk acute myocardial infarction. Ann Intern Med 2004:141:693-704.

45 The ONTARGET/TRANSCFND Investigators. Rationale, design, and baseline characteristics of 2 large, simple, randomized trials evaluating telmisartan, ramipril, and their combination in high-risk patients: the ongoing telmisartan alone and in combination with ramipril global endpoint trial/telmisartan randomized assessment study in ACE intolerant subjects with cardiovascular disease (ONTARGET/TRANSCEND) trials. An Heart J 2004;148:52-61

(Accepted 1 August 2005)

doi $10.1136 /$ bmj.38595.518542.3A

Division of Cardiology, University of Alberta, 2C2 WMC, University of Alberta Hospital, 8440-112 Street, Edmonton, AB, Canada T6G 2B7

Michael A McDonald resident, cardiology

Faculty of Pharmacy and Pharmaceutical Sciences, University of Alberta. 3126 Dentistry-Pharmacy Centre, Edmonton, AB, Canada T6G 2N8

Scot H Simpson assistant professor

Division of Cardiology, University of Alberta

Justin A Ezekowitz resident, cardiology

Gabor Gyenes assistant professor of medicine (cardiolog))

Ross T Tsuyuki professor of medicine (cardiology)

Correspondence to: R T Tsuyuki ross.tsuyuki@ualberta.ca 